\title{
Empowerment Strategy on Micro, Small, and Medium Enterprises (MSMEs) During COVID-19 Pandemic in Indonesia: A Case Study of BRI Microfinance Center
}

\author{
Dhayita Rukti Tanaya ${ }^{1 *}$ and Fandis Ekyawan $^{2}$ \\ ${ }^{1}$ Master of Management, Faculty of Economic and Business, University of Indonesia \\ ${ }^{2}$ Lembaga Management (The Management Institute), University of Indonesia
}

\begin{abstract}
Many Micro, Small, and Medium Enterprises (MSMEs) are impacted by COVID-19 pandemic in Indonesia, especially the ones who hasn't fully adapted to the industrial revolution 4.0. Therefore, the right empowerment strategy is needed to develop the MSMEs and help them to strive during COVID-19 pandemic. Hence, this paper presents a research to evaluate the empowerment strategy of Indonesian MSMEs implemented by the BRI Microfinance Center (BMC), an independent research institution under BRI Group as the leader of microfinance in Indonesia. This research also analyse the potentials and problems faced by BMC in conducting their empowerment effort during the pandemic and formulate alternative strategies as recommendation for future improvement. As a case study with descriptive qualitative approach, the data collections are done by in-depth interviews on BMC's key people and literature studies on supporting documents, and triangulation. The result presented in this paper has important points to deeply understand the existing MSMEs empowerment strategy in Indonesia implemented by BMC, the strategy shifts during the pandemic, and recommendations for strategy improvements. This paper will also complete similar researches regarding the studies on empowerment strategy to enhance the MSME's competitiveness in Indonesia.
\end{abstract}

\section{Introduction}

Modernization has become an important factor in all fields of industry in the world. Technology is not only acting as a complement, but also a necessity, both for business actors and the public as users [1], especially with the new era of the industrial revolution 4.0, which is vigorously voiced throughout the world, including Indonesia [2]. Significant changes that became an impact of the industrial revolution 4.0 is the concept of the Internet of Things (IoT), which means that the internet is a crucial part in every business unit in all industrial sectors, including Micro, Small and Medium Enterprises (MSMEs). As one of the most significant contributors to economic growth in Indonesia, by the end of 2018, there were 63.3 million micro business units, 783,132 small business units, and 60,702 medium business

* Corresponding author: dhayita.rukti@,ui.ac.id 
units [3]. This number is a sizable amount for developing countries like Indonesia. As a cog in the national economy, MSMEs not only contribute to the economy but also to the employment rate. Even so, MSMEs have many problems, such as branding, determining representative designs, attractive packaging designs, capital issues, and access to marketing, along with the limited working capitals, lack of adequate human resources, and lack of mastery of science and technology $[4,5,6]$.

The COVID-19 pandemic hit Indonesia in March 2020 and many businesses are deeply impacted, especially in MSMEs sectors. There have been more than 950 cooperatives and MSMEs sectors reported to be impacted, with $68 \%$ experience income reduction, $6 \%$ complain about the raw materials scarcity, $10 \%$ have late distribution problems, $12 \%$ have difficulty in working capitals, and 4\% claimed to have late production [7]. As the economy has been struggling ever since, many people has been pessimistic and unsure about the economic recovery with 50-70\% reduce in their household income [8] (McKinsey \& Company, 2020).

Facing this crisis, it is necessary to empower MSMEs to survive for the stability of the Indonesian economy. To position MSMEs in the national economy, the breakthrough of innovation is not only becoming the task of MSMEs actors but also becoming a homework for the MSMEs empowerment providers. In order to strive, the empowerment of MSMEs in Indonesia must also target the improvement of product and service innovation, the development of human resources and technology, and the expansion of the marketing distribution of products and services.

The President of the Republic of Indonesia has declared the nation's programmes for economic protection and recovery for MSMEs, including the scheme where the government institutions and State-Owned Enterprises (SOEs) will be acting as a buffer in defending the MSMEs ecosystems [9] (Indonesian Task Force for the Acceleration of Handling COVID19, 2020), and one of the efforts is through MSMEs empowerment. Regarding this matter, Bank Rakyat Indonesia (BRI) seeks to continue its efforts in optimizing the empowerment of MSMEs in Indonesia to be able to survive and compete in the global market, not only providing capital access assistance but also mentoring incubation and technology programs. As a form of BRI's contribution to National Capacity Building in the MSMEs segment, BRI launched the BRI Microfinance Center (BMC) in early 2019 as a research and consulting institution focused on boosting the productivity of the MSMEs business in Indonesia [10]. The services offered by BMC to improve the quality of MSMEs in Indonesia range from research on microfinance and MSMEs concerning financial inclusion and poverty reduction efforts, training, and assistance in various sectors including MSMEs who want to develop their businesses from upstream-downstream, to consultations related to entrepreneurship development, including for MSMEs. BMC also facilitates MSMEs actors to adapt to the industrial revolution 4.0 era by digitizing the empowerment modes. One of the instruments used by BMC is to develop a digital platform called Wirausaha BRIlian. Until today, BMC has carried out MSME empowerment programs for various industrial fields in Indonesia. Therefore, research is needed to evaluate the empowerment strategies that have been carried out by BMC in empowering MSMEs, examine the strategy shifts during COVID-19 pandemic, and formulate alternative strategies as recommendations for future improvement.

There are several studies conducted to gain a better understanding about community and MSMEs empowerment, but there is still a few research that studies MSMEs empowerment strategies implemented by government or non-government institutions, specifically in banking industries specialize in microfinance. Thus, this paper will probe into BMC's strategy in empowering MSMEs, especially in the fact that BMC is a part of BRI Group as the leader of microfinance in Indonesia. By having the in-depth knowledge of the MSMEs empowerment strategy implemented by BMC, both practitioners and academicians can have 
a deeper understanding of the matter and profound inputs for benchmarking and improving the MSME empowerment strategies.

\section{Literature Review}

\subsection{MSMEs and Entrepreneurship in Indonesia}

Entering the era of the industrial revolution 4.0, digitization, computerization, and the use of artificial intelligence in economic activities can rapidly increase productivity and efficiency in modern production and provide convenience and comfort for consumers. However, this also raises new challenges, one of which is the potential for job losses in the world. A study from McKinsey [11] states that $60 \%$ of the world's work is expected to be replaced by automation and robots. In Indonesia, it is estimated that $51.8 \%$ of jobs will potentially be lost; this is a new challenge for all business people in Indonesia, especially for the MSME sector. The capacity of national industries to process and export high value-added products and compete on a global scale is still limited. This condition causes the growth of the national industry's added value in 2015-2018, which is lower than the average national growth. To encourage the improvement of these problems, Indonesia needs to increase the capacity and adds value in various sectors, especially in micro, small, and medium enterprises (MSMEs), because MSMEs contribute significantly to employment in Indonesia. The number of MSME units increased by $2.02 \%$ from 2017 to 2018 , which was $64,194,057$ business units, which were dominated by 63,350,222 micro business units, 783,132 small business units, and 60,702 medium business units. Of this amount, employment in the MSME sector in 2018 was $116,978,632$ people, with a GDP of IDR 8,573,895,300, which showed an increase of 9.64\% from 2017 (Kementerian Koperasi dan Usaha Kecil dan Menengah, 2019).

Many factors are correlated in the decisions to work in MSMEs sectors, however, one of the factor considered to be the initial push is the entrepreneurship thrust. In a research conducted by Tambunan (2019), he stated that most micro businesses are still operating in informal sectors with traditional systems and mobilizing their labour from close relatives [12]. Their business orientation is still on the local market scale and they conduct their businesses to survive, hence, they are still lacking of entrepreneurial spirit. Those matters can be a basis for formulating MSMEs empowerment strategies, by considering the business characters.

Human resource management is also important for MSMEs, which are widely different with the ones in Large Enterprises. Not only in terms of company scale and priority, but also in terms of formality, where MSMEs tend to prioritize entrepreneurship with a more informal atmosphere without professional Human Resources and a more informal training model with an emphasis on learning methods with their peer and supervisors [13]. Therefore, in order to grow rapidly and be successful in contributing to the economy and creating new jobs, empowerment efforts are needed from institutions who have more resources and authority to guide the MSMEs.

\subsection{MSMEs Empowerment}

According to Sumaryadi (2005), the success of any empowerment program is determined by the success of the program to fulfil the four principles [14]: (1) the principle of equality (between the object and the institutions conducting the empowerment); (2) the principle of participation (encouraging the ability of the object of empowerment to build their commitment to develop themselves); (3) the principle of independence (prioritizing the ability of the object of empowerment, so that after empowerment there will be changes from 
within and in the end they can manage their own resources optimally); and (4) the principle of sustainability (targeting long-term and sustainable improvements, so that in the end the object of empowerment is able to empower themselves).

In the relations of MSMEs with entrepreneurship, based on the McMullen-Shepherd model [15], entrepreneurial activities and decisions taken are influenced by knowledge and motivation. Thus, the more knowledge a business person has, including about the environment and natural ecosystems, biodiversity, climate change, and the physical condition of the earth, the more likely they are to pay attention to changing phenomena in their environment, and the higher their chances of finding business opportunities, compared to those with less knowledge. Therefore, empowerment becomes very important to open the door for ideas to become wider for business people, especially for MSMEs. Empowerment will also broaden the gap to develop and expand the network, including professional-support networks, because access to new information and knowledge will be more open, and the potential to see more opportunities will increase. In other words, the empowerment of MSMEs will also be in line with the breakthroughs of disruptive innovation.

\section{Research Methods}

This paper presents a case study, which is research as a system of analysis by one or more methods that have a comprehensive view of something that is studied holistically, with the main emphasis on the research as an analytical design framework and not just a method, so that the main focus is in the case studied as the object of the research, regardless of the methods used. The approach used in this case study is a qualitative research approach, which aims to obtain a complete picture of something according to the view of the object under study, with an emphasis on the expansion or depth of information [16]. Furthermore, the approach used is descriptive qualitative, which aims to describe, explain, and summarize various conditions, situations, or phenomena that are the object of research, and attempt to draw these observations as a description of certain phenomena [17].

Thomas (2011) stated that there are three ways to determine the subject of case study research: local knowledge cases, key cases, and outlier cases [18]. In this case study, the research subject is the MSMEs empowerment strategy in Indonesia, based on the key case principle, namely the empowerment of MSMEs which is increasingly needed in Indonesia especially during COVID-19 pandemic.

With the MSMEs empowerment strategy as the research subject, the author then sharpens the focus of this case study by determining the research object to be studied, which is BRI Microfinance Center (BMC) as a new independent institution that conducts the empowerment efforts to develop MSMEs in Indonesia as one of the company's main activities. Thus, this case study is focused on examining the strategy of empowering MSMEs carried out by BMC. Through this research, the author tries to explore the MSMEs empowerment strategy that has been implemented by BMC, to be able to produce a detailed description of the strategy being applied and then to explore the potential and problems faced by BMC in carrying out the empowerment strategy, especially during COVID-19 pandemic in Indonesia. Finally, the authors aims to formulate alternative strategies that can be recommended for future improvements.

After determining the subject and object of the case study research and its objectives, it is necessary to examine the methods to be used in the research. In this regard, Thomas (2011) describes six types of case studies, which are summarized in the Table 1. 
Table 1. Types of case study based on the analysis used

\begin{tabular}{|c|c|c|c|c|c|c|}
\hline $\begin{array}{l}\text { George \& } \\
\text { Bennett } \\
(2005, \text { from } \\
\text { Eckstein, } \\
1975)\end{array}$ & $\begin{array}{l}\text { Merriam } \\
(1988)\end{array}$ & $\begin{array}{l}\text { Stake } \\
(1995)\end{array}$ & $\begin{array}{l}\text { Bassey } \\
\text { (1999) }\end{array}$ & $\begin{array}{l}\text { de Vaus } \\
(2001)\end{array}$ & $\begin{array}{l}\text { Mitchell } \\
(2006, \\
\text { mengutip } \\
\text { Eckstein, } \\
1975)\end{array}$ & Yin (2009) \\
\hline $\begin{array}{l}\text { Theory- } \\
\text { testing }\end{array}$ & $\begin{array}{l}\text { Descripti } \\
\text { ve }\end{array}$ & Intrinsic & $\begin{array}{l}\text { Theory } \\
\text { seeking }\end{array}$ & $\begin{array}{l}\text { Descripti } \\
\text { ve/ } \\
\text { explanato } \\
\text { ry }\end{array}$ & $\begin{array}{l}\text { Illustrativ } \\
\text { e }\end{array}$ & Critical \\
\hline $\begin{array}{l}\text { Atheoretical/ } \\
\text { configurati } \\
\text { ve- } \\
\text { idiographi } \\
\text { c }\end{array}$ & $\begin{array}{l}\text { Interpreta } \\
\text { tive }\end{array}$ & $\begin{array}{l}\text { Instrumen } \\
\text { tal }\end{array}$ & $\begin{array}{l}\text { Theory } \\
\text { testing }\end{array}$ & $\begin{array}{l}\text { Theory } \\
\text { testing/ } \\
\text { theory } \\
\text { building }\end{array}$ & $\begin{array}{l}\text { Social } \\
\text { analytic }\end{array}$ & $\begin{array}{l}\text { Extreme/ } \\
\text { unique }\end{array}$ \\
\hline $\begin{array}{l}\text { Disciplined } \\
\text { configurati } \\
\text { ve }\end{array}$ & $\begin{array}{l}\text { Evaluativ } \\
\text { e }\end{array}$ & $\begin{array}{l}\text { Single/ } \\
\text { collective }\end{array}$ & $\begin{array}{l}\text { Storytelli } \\
\text { ng }\end{array}$ & $\begin{array}{l}\text { Single/ } \\
\text { multiple } \\
\text { case }\end{array}$ & $\begin{array}{l}\text { Extended } \\
\text { (overtime } \\
\text { ) }\end{array}$ & $\begin{array}{l}\text { Longitudin } \\
\text { al }\end{array}$ \\
\hline Heuristic & - & - & $\begin{array}{l}\text { Picture } \\
\text { drawing }\end{array}$ & $\begin{array}{l}\text { Holistic/ } \\
\text { embedded }\end{array}$ & $\begin{array}{l}\text { Configura } \\
\text { tive- } \\
\text { idiographi } \\
\text { c }\end{array}$ & $\begin{array}{l}\text { Representat } \\
\text { ive }\end{array}$ \\
\hline $\begin{array}{c}\text { Plausibility } \\
\text { probes }\end{array}$ & - & - & $\begin{array}{l}\text { Evaluativ } \\
\text { e }\end{array}$ & $\begin{array}{l}\text { Parallel/ } \\
\text { sequential }\end{array}$ & $\begin{array}{l}\text { Discipline } \\
\text { d- } \\
\text { configurat } \\
\text { ive }\end{array}$ & Revelatory \\
\hline $\begin{array}{l}\text { "Building } \\
\text { block" } \\
\text { studies }\end{array}$ & - & - & - & $\begin{array}{l}\text { Retrospec } \\
\text { tive/ } \\
\text { prospecti } \\
\text { ve }\end{array}$ & $\begin{array}{l}\text { Heuristic, } \\
\text { Plausibilit } \\
\text { y probes }\end{array}$ & - \\
\hline
\end{tabular}

Based on the explanation of the type of case study above, the author identifies the type of research conducted as the type of plausibility probes, which is evaluative research conducted to reveal the phenomenon under study: the MSMEs empowerment strategy implemented by $\mathrm{BMC}$, its potential and problems especially during COVID-19 pandemic, as well as alternative strategies that can be recommended to determine whether further studies are needed or not. Thus, this case study research aims to be evaluative and explorative with a qualitative descriptive research approach, by examining several elements that have been summarized into the formulation of the problems to be answered through this research. 
To determine the scope and the form of the case studies conducted, Thomas (2011) summarizes the research process into several categories according to the type of study. Referring to this category, this case study is categorized as a multiple case study conducted sequentially, which as a whole is depicted in the chart in Figure 1.

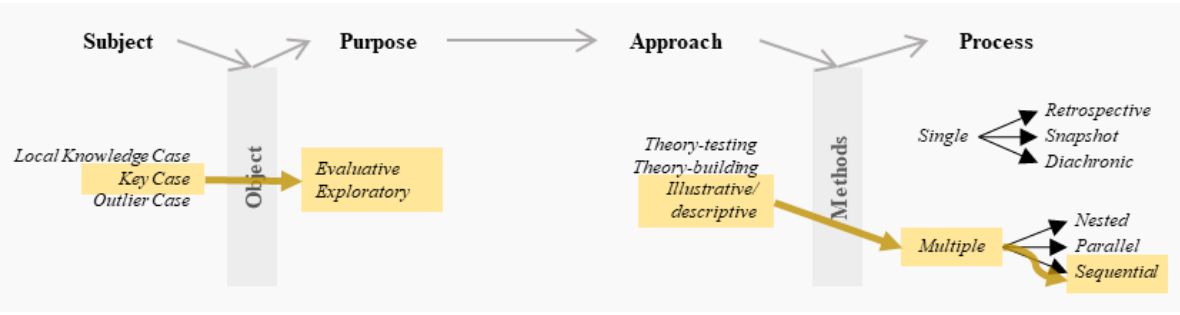

Fig. 1. Typology of case study used in this research.

In carrying out the research as described in the chart above, the author uses two types of data. The first type of data is the primary data, which are obtained from in-depth interviews conducted on several key people, which are the Operational Director and the Networking Manager at BMC. The key people are determined using purposive sampling method based on the mastery of information from informants and their involvement, which in this case are the actors who conduct the MSMEs empowerment programs hands-on. The reason for selecting the informants is not only based on the availability of resource schedules during the COVID-19 pandemic, it is also based on in-depth knowledge and job specifications of sources that are directly related to the MSMEs empowerment strategies implemented by $\mathrm{BMC}$. In addition, the data from the two sources are sufficient to describe the answers for the research questions through detailed interviews, while still not straying from the focus of this case study. From the results of interviews and triangulation with the two key sources, the resulting data is saturated and credible to describe the overall activities of BMC related to the MSMEs empowerment strategies. The second type of data is secondary data, which are collected from official company reports, company web pages, books, journals, reports, articles, regulations, or other literatures that are relevant to the problems discussed in this study.

The analytical method used in this qualitative research includes the analysis of the transcript as the results of structured interviews with informants, data reduction, analysis, data interpretation, and triangulation. Furthermore, the author then draws conclusions from the results of the overall analysis. Another method used by the author is the triangulation method, in which the effectiveness of the process and the desired results are prioritized in checking the data validity, which can be done by testing whether the data collection process and analysis methods are running well. In addition, the author also examine the strategy shifts during COVID-19 pandemic to highlight the main efforts that is implemented by BMC to continue their MSMEs empowerment efforts. Finally, the author formulates the alternative strategies for future improvements from the triangulation analysis to determine which strategies to be prioritized. 


\section{Results and Discussion}

\subsection{Evaluation of the Existing MSMEs Empowerment Strategy}

In order to evaluate the strategy for empowering MSMEs by BMCs, it is necessary to first understand the company management as well as the strategic management implemented by BMC. Based on the interviews and literature reviews that have been conducted, several important points can be concluded by the analysis of company management applied by BMC related to the MSMEs empowerment strategy. The four main points are that (1) BMC is an independent research, consulting, and networking institution that focuses on developing the microfinance and MSMEs sector in Indonesia; (2) microfinance and MSMEs development programs carried out by BMC are in the forms of research and study activities, technical assistance and training, consultation and advocacy, as well as community and institutional empowerment; (3) as an independent institution, the implementation of BMC programs is based on BMC initiatives and agreements with stakeholders; and (4) BMC implements the company's core values into its programs with MSMEs as the main objective, which are integrity, trust, networking, and innovation.

Furthermore, the author analyses the strategic management implemented by BMC. To assess the corporate strategy implemented by BMC, it is necessary to analyze the external and internal factors that influence the company. Although BMC programs are a derivative of BRI's programs, so that the company's programs predate the company's strategies, the applied corporate strategy has taken macro and micro environmental factors into account [19], in accordance with Thompson et.al. (2018) statements regarding the determination of the right company strategy. Based on the results of the analysis that has been carried out, every aspect from external and internal has been accommodated by BMC through its corporate strategy, which in relation to the MSME empowerment strategy is then divided into offline and online empowerment efforts.

After conducting management analysis and strategic management analysis in relation to the BMC's MSMEs empowerment strategy, the author then evaluate the MSMEs empowerment strategy implemented by BMC. Based on the data that have been collected, it can be concluded that the series of company activities carried out by BMC are focused on two main activities, which are research and empowerment. Generally, the dimensions of the MSMEs empowerment programs carried out by BMC include mentoring and training activities, consultation and advocacy, as well as community and institutional empowerment. These MSME empowerment efforts are carried out both offline and online. The existing MSMEs empowerment strategy that has been implemented by BMC can be summarized in the chart in Figure 2. 


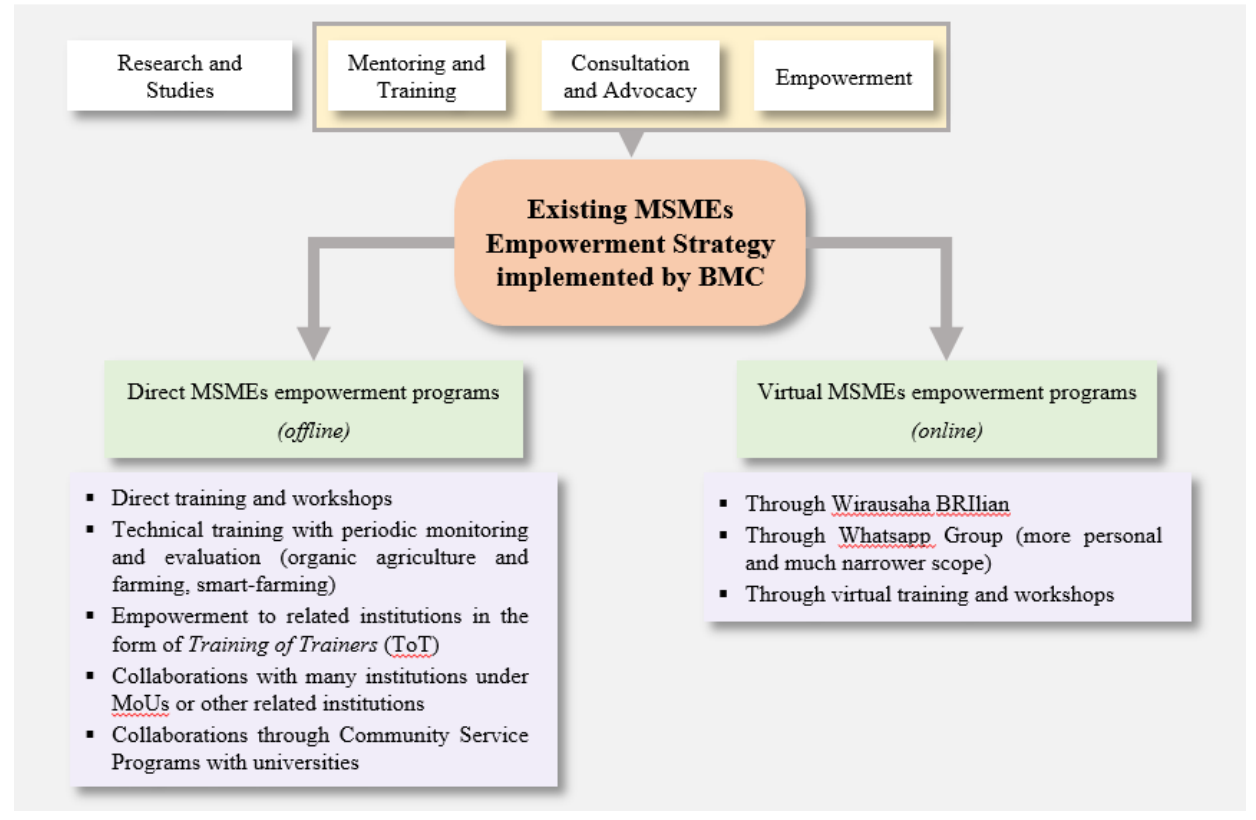

Fig. 2. The existing MSMEs empowerment strategy implemented by BMC.

Rapid technological developments require BMC to always innovate to provide the best services, especially in empowering MSMEs. One of them is by providing an integrated digital platform called Wirausaha BRIlian, as a form of BMC support for Indonesian MSMEs to upgrade their classes. The application can be accessed by anyone, through the website at wirausahabrilian.bri.co.id or downloaded on smartphones via Google Play Store or App Store. The application aims to make it easier for MSMEs actors to continue to get access to information and online empowerment wherever and whenever.

According to BMC's research in 2019, approximately 67\% of MSMEs players in Indonesia are millennials [20], which are more exposed to the industrial revolution 4.0. Hence, BMC facilitate the empowerment strategy with integrated online platform, Wirausaha BRIlian. Within the platform, they in still their core values, giving the access for MSMEs players to retrieve information and independently developing themselves and their businesses. MSMEs players can also ask for free consultations regarding their businesses, join or make any community with similar business interests, and promote their businesses. They also facilitate MSMEs players to get free training modules and watch videos to help them develop their businesses. This online empowerment platform is provided as one of many efforts in promoting Indonesian MSMEs to grow. 


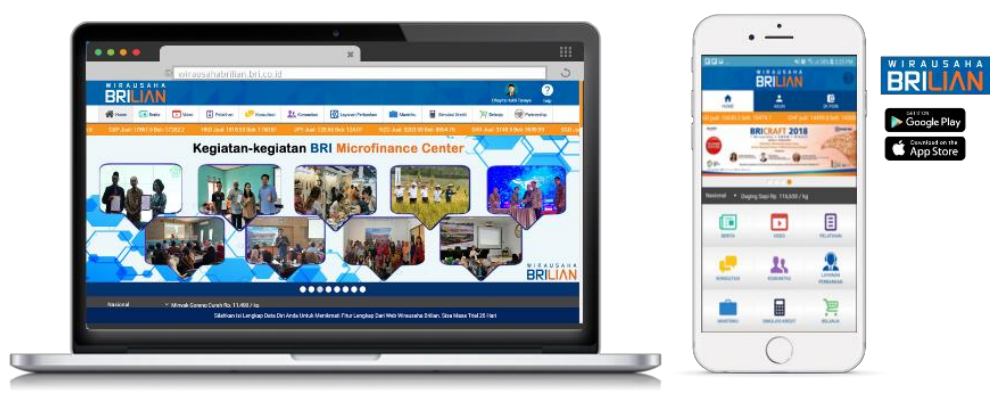

Fig. 3. Integrated empowerment platform through Wirausaha BRIlian.

Aside from Wirausaha BRIlian, BMC has four main business activities, which are research and studies, mentoring and training, consultation and advocacy, and empowerment. In 2019, BMC has conducted several research and studies regarding microfinance in Indonesia and helping many stakeholders in improving their business models. There has been 10-15 research conducted in a year. Those research can be used as inputs for legislation and policy makers in formulating regulations relating to MSMEs and microfinance, specifically financial inclusion and poverty alleviation. One of the objectives of the research conducted by BMC is to support bank and non-bank financial institutions to be more creative and effective in serving customers from the MSMEs sector.

$\mathrm{BMC}$ has assigned a number of advisors as the experts in specific fields to help with their research, and also signed MoUs with 18 universities and institutions to collaborate in empowering the MSMEs in Indonesia. For specific types of technical assistance, training, and consultation, these advisors will help in providing expertise and facilities to help empower the targeted MSMEs or institutions. The main point highlighted from the in-depth interview with the Director of Operational and Manager of Networking is that one of BMC's objectives are to develop MSMEs in Indonesia in all aspects, starting from the business players and their capacity building, the institutions, the technology, the operational, the policymakers, up until the regulations.

In general, the empowerment strategy implemented by BMC aligned with the principal of empowerment stated by Sumaryadi (2005), which are (1) the principle of equality; (2) the principle of participation; (3) the principle of independency; and (4) the principle of sustainability. All of the principles are implemented within the online and offline empowerment programs. BMC's Director of Operational also stated that their empowerment efforts are synergized with BRI's empowerment programmes, which covers the needs for solutions in microfinancing and empowering the MSMEs in Indonesia.

Furthermore, the MSMEs empowerment strategy implemented by BMC also aligned with the principles of empowering MSMEs as stated in Law Number 20 of 2008, which are the principles of independence, entrepreneurship, transparency, market orientation and regional potential, seeks to improve the competitiveness of MSMEs, and is planned and implemented in an integrated manner [21]. The MSMEs empowerment strategy implemented by BMC is also in accordance with the goal of empowering MSMEs in Presidential Regulation Number 2 of 2015 concerning the 2015-2019 National Medium-Term Development Plan (RPJMN), which is to improve the quality of human resources for MSMEs business players through increasing the entrepreneurial spirit, training and mentoring, as well as increasing the added value of the products and services offered by the assisted MSMEs [22]. As for the principle of five fingers (Five Fingers Philosophy) [23] empowerment of MSMEs by Bank Indonesia, the strategy adopted by BMC is included in the philosophy of the ring finger, which is to act as a facilitator to assist MSMEs. 


\subsection{Strategy Shifts During COVID-19 Pandemic}

By mid-April 2020, the Ministry of Cooperatives and Small and Medium Enterprises of Republic of Indonesia announced the number of MSMEs impacted by the crisis, which was reaching 37.000 businesses, with $87 \%$ came from micro enterprises with no emergency savings [24]. From those numbers, $47 \%$ of MSMEs had to close their business by the end of May [25]. The most badly impacted MSMEs are from hotel and tourism sector due to the policy of social distancing for slowing the spreading of the virus, which has a domino effect to several other MSMEs. Indonesian Institute of Science reported the impact of the declining number in tourism to MSMEs in Food \& Beverages (F\&B) businesses, which reach the number of $27 \%$ of micro enterprises, $1.77 \%$ for small enterprises, and $0.77 \%$ for medium enterprises by March 2020 [26].

The government has implemented the MSMEs protection and recovery schemes to help them surviving the downfall, which include these five efforts: (1) distributing social assistance through funding for poor and vulnerable MSMEs; (2) tax incentives for MSMEs with under IDR 4.8 billion per year turnover; (3) credit relaxation and restructuration for MSMEs; (4) financing expansion of working capital for 23 million of MSMEs which haven't been connecting with banking financial institutions; and (5) government institutions and SOEs as MSMEs buffer (Gugus Tugas Percepatan Penanganan COVID-19 Indonesia, 2020).

Although the government has been helping with the financial assistance, MSMEs players still need to find their entrepreneurship spirit to rise and survive. During the crisis, BMC continue to provide the empowerment services. Although the offline trainings, visitations, and events have to be postponed, the main platform still exist with better adjustments. As the Minister of Cooperatives and Small and Medium Enterprises, Teten Masduki, has declared the "Stay at Home Economy" as one of the solutions in giving MSMEs opportunities to survive and maintain their business productivities [27], BMC has since increase the intensity of information sharing and online empowerment efforts through Wirausaha BRIlian platform.

When the Indonesian Government is promoting "Stay At Home Economy" into a new trend, through e-commerce and the movement to support local businesses, BMC must also consider more visionary solutions to empower MSMEs in order to accelerate their operations so that they recover faster. Baig et.al (2020) through a McKinsey \& Company article provide several alternatives from their study to compile solutions for recovery, such as through digitizing some parts of the MSME business [28]. This must be a major consideration for $\mathrm{BMC}$ and other institutions to encourage the use of the internet for business, because many MSMEs in Indonesia still use traditional ways of doing business [12].

Utilizing social media, BMC adapts to the trends and provide virtual workshops and trainings as well as talkshows, not only for the members who have already signed up in Wirausaha BRIlian to access BRIlian TV, but BMC also facilitates live streaming through YouTube and their official Instagram account and also provide live access to their virtual events through Zoom Meeting. Through these efforts, MSMEs actors are forced to adapt to digitalization and IoT in order for their businesses to survive.

In the latest virtual empowerment effort, BMC collaborates with Ministry of Villages, Disadvantaged Regions, and Transmigration, encourage people to join the workshop through Zoom Meeting for better experience in getting the information. The same type of virtual workshop had been done before with different topics with different institution to collaborate, which was the Ministry of Environment and Forestry. With this "new normal", people are more encouraged to develop themselves and their businesses. BMC's Manager of Networking also stated that during this crisis, people are forced to survive, which sparks their entrepreneurship thrusts to think of any way for their business to strive. 


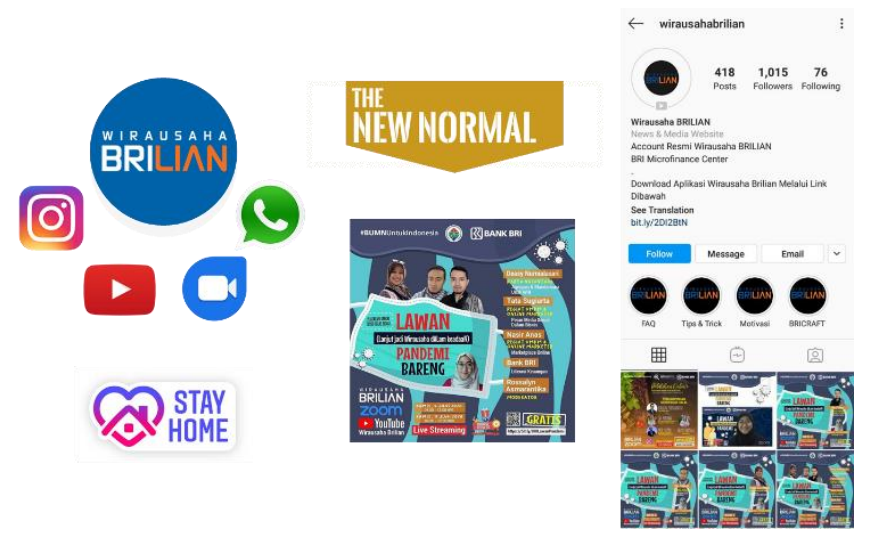

Fig. 4. Virtual empowerment strategies during COVID-19 pandemic.

From previous training and workshop programs provided by BMC, MSMEs players are listed in Whatsapp Groups to directly consult with BMC's executives as one of its empowerment efforts in this crisis. Many of the MSMEs players still face difficulties in adapting, but slowly they are guided to self-motivating for innovating their businesses if their current business couldn't strive. For example, MSMEs in clothes and garment started to innovate in selling reusable masks, restaurants and café owners start innovating in selling ready-to-cook and ready-to-drink products, F\&B business players start selling bundleproducts, and many more. The positive takes from this pandemic is MSMEs players starting to think like entrepreneurs, which many of them haven't before.

\subsection{Alternative Strategies for Future Improvements}

Although this research describe the strategy implemented by BMC to empower MSMEs during COVID-19 pandemic, there is still no accurate prediction in when this crisis will end. However, MSMEs players should keep their innovations, not only to survive but also to prepare their business to operate with more productivity post-COVID-19, as the data from countries in recovery phase shows the consumption pattern returns almost immediately.

The graphic in Figure 5 shows that the consumption patterns in China have already jumped back to normal after COVID-19 peak in March 2020. During the lockdown and COVID-19 peak, the daily average consumption level decreased from above $150 \%$ in Chinese Lunar Year to below 50\%, but after the emergency response level is lowered in many regions in China, the patterns started to rise up more than twice [28]. This should be taken into consideration in empowering MSMEs to also prepare their business to welcome the returns of the consumers.

Taking into the account of the strict lockdown in China, the offline consumption pattern immediately rose up. Although Indonesia does not apply the same type of lockdown or any strict lockdown, if the entire population adhere to the health protocol established by the government and WHO, the peak should subdue and the consumption rate and all business activities will start recovering. In that case, all business players should not only adapt to the new normal but also prepare for the post-normal or the new normal 2.0, so it is recommended 
for business players to have short-term and long-term plan for their businesses. These matters should be considered when planning the next empowerment strategies.

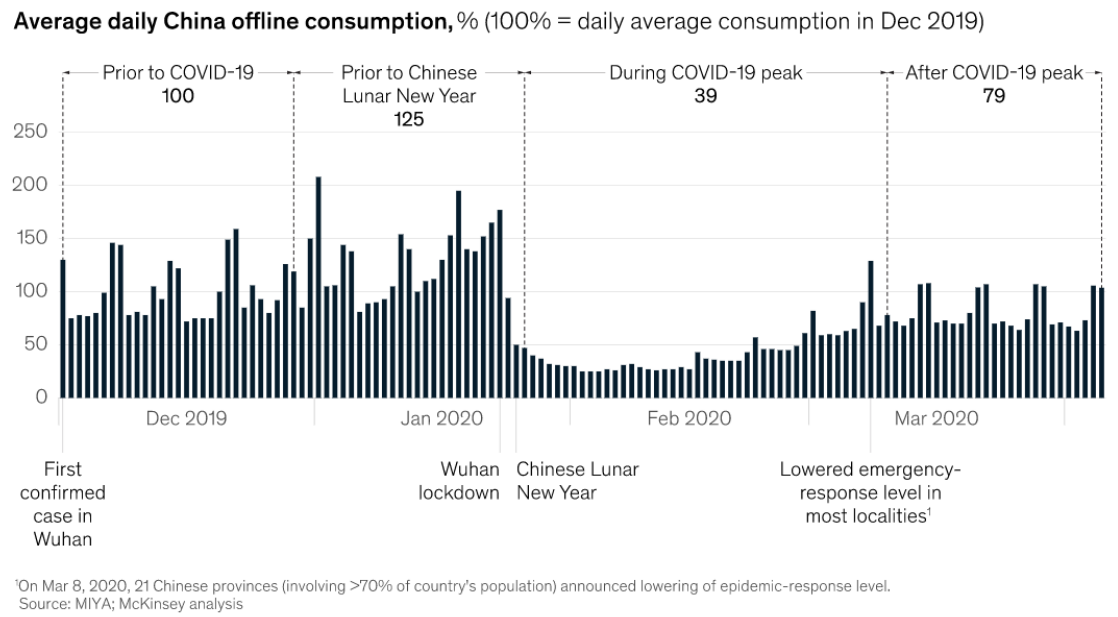

Fig. 5. China's offline consumption pattern during COVID-19 peak and immediately after the peak.

McKinsey's \& Company [28] provided an alternative plan for recovery post-COVID-19, which is shown in Figure 6. Those alternative can be studied to be applied in Indonesian MSMEs empowerment programs, with adjusting the plans with the conditions in Indonesia. Before and during COVID-19 pandemic in Indonesia, MSMEs are facing difficulties in marketing their products and maintaining agile business operations. These alternatives will be one of the solutions in solving those problems, while at the same time leading the MSMEs to fully enter industrial revolution 4.0 and actualize governments grand program of Making Indonesia 4.0 [29]. Considering the current condition in Indonesia, more empowerment efforts are needed in recovering Indonesian economic growth through MSMEs. Although government programmes are already focusing in helping those in needs, more action and initiative are needed from MSMEs players to be optimistic and motivated to keep their businesses afloat and survive the crisis.

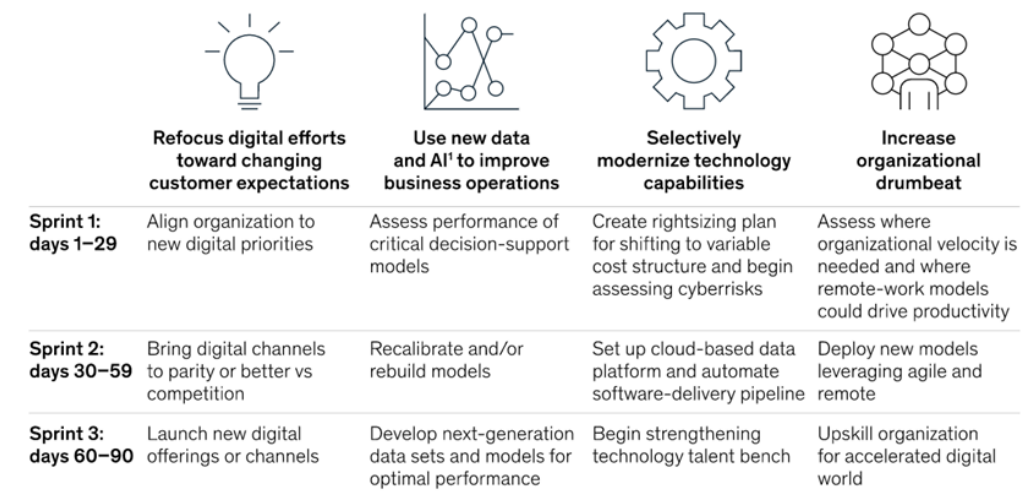

Fig. 6. First 90 days digital recovery plan by McKinsey \& Company. 
As the rate of COVID-19 cases in Indonesia that is still increasing [30] and seeing the new potential where the pandemic forces business players to survive so that entrepreneurial thrusts begin to emerge, the next proposed strategy is to increase the intensity of virtual workshops \& trainings and talk shows on interesting topics. Not only raising the awareness on the topic of capacity building, increasing human resource capacity and sustainable entrepreneurship, and increasing soft skills, but also light topics to provide tips \& tricks to sustain business during a pandemic and prepare for post-pandemic business recovery.

Furthermore, based on the analysis resulted and the additional triangulation conducted by the author, the next alternative strategy that could be recommended is to improve the performance and the interface of Wirausaha BRIlian as the main platform for integrated MSMEs empowerment with interactive features, in order to provide assistance that seems as personal as the assistance through Whatsapp Group. With limited human resources at BMC at this time, assistance through Whatsapp Group is quite time-consuming and energyconsuming, and not all questions and consultations can be handled optimally. To minimize this problems, the author recommends the additional interactive features in Wirausaha BRIlian, such as a chat box that gives users access to ask any questions and the system will identify the keywords of these questions and provide answers according to the FAQ data that has been input into the system. If the question is technical and is not recorded in the FAQ, the user can input a ticket which can be filled with more detailed things that they want to ask which will automatically be sent via email to the relevant executives so that it can be answered immediately. In fact, this kind of system has been widely used by companies both providing products and services, either using automated customer services such as chatbots or other forms of Artificial Intelligence. This is intended to reduce the work load and work costs of supporting human resources who become representatives to this app. The use of automation is also intended so that Wirausaha BRIlian consulting and empowerment services can be accessed anywhere and anytime and can also provide a 24/7 consultation responses. In building this feature, BMC does not have to recruit special IT staffs, especially during this pandemic, but BMC can explore several third party companies that offer these services. Of course this should be adjusted to the BMC's budget in developing the platform. However, as BMC's main empowerment platform, Wirausaha BRIlian should get an upgrade so that its services can be more user-friendly and can be enjoyed by anyone.

Lastly, the socialization of the empowerment programs should be increased so people more aware of BMC's strategy in contributing to the MSMEs development in Indonesia. In this case, the strategy that can be proposed is related to company organization and collaboration, such as by adding organizational functions and allocating human resources to focus on carrying out public relations and marketing activities, as well as collaboration with various figures or agencies to help socialization. Socialization activities can also be started by improving the performance of Wirausaha BRIlian website and application, using SEO tools to increase the traffic to the website and ultimately increasing the number of users of the application. Apart from the uploaded news into the platform, SEO tools can also be applied to other uploaded posts. In this case, it is proposed to add publications related to BMC programs as well as the results of research and studies that have been carried out that have been processed so that they can be published and easier to digest by anyone. This can also be a form of socialization, not only for business people, but also for agencies that have the potentials to collaborate with BMC in the future.

\section{Conclusions}

MSMEs empowerment strategy implemented by BRI Microfinance Center (BMC) during COVID-19 Pandemic in Indonesia has shown its commitment in helping MSMEs players to save their businesses through their ideas and innovation. This shows that funding assistance 
is not the main factor in maintaining the business - it is the determination to survive and develop the businesses, which are still a rather difficult task for MSMEs players in Indonesia, especially during this crisis. Therefore, more empowerment programmes are needed, not only from BMC but also from other institutes who have resources to empower. More studies are also needed to determine the effective strategy to empower MSMEs during COVID-19 pandemic and to prepare them to fully recover post-COVID-19 pandemic.

\section{References}

1. Google, Temasek, Bain \& Company, e-Conomy SEA 2019, presented in Asia's Blockbuster Conference, Jakarta Convention Center, Indonesia (2019)

2. Wulan Ayodya, UMKM 4.0: Strategi UMKM Memasuki Era Digital, Jakarta: PT Elex Media Komputindo (2020)

3. Kementerian Koperasi dan Usaha Kecil dan Menengah, Data of Micro, Small and Medium Enterprises (MSMEs) and Big Business Development on 2017-2018 (2019)

4. Sudaryanto, Ragimun Abdullah, Rahma Rina Wijayanti, Strategi Pemberdayaan UMKM Menghadapi Pasar Bebas ASEAN, Jakarta: Pusat Kebijakan Ekonomi Makro, Badan Kebijakan Fiskal, Kementerian Keuangan (2013)

5. Bernhart Farras, UMKM Kalah Saing, Jokowi Beberkan Masalahnya, retrieved from https://www.cnbcindonesia.com/news/20190111134416-4-50214/umkm-kalah-saingjokowi-beberkan-masalahnya (2019)

6. Sakina Rakhma Diah Setiawan, Mengapa Masih Banyak UMKM Indonesia yang Belum Go-Digital?, retrieved from https://ekonomi.kompas.com/read/2019/02/12/152246426/mengapa-masih-banyakumkm-indonesia-yang-belum-go-digital (2019)

7. Elsa Catriana, Terpukul Corona, Ini 5 Keluhan Para Pelaku UMKM, retrieved from https://money.kompas.com/read/2020/03/27/190000026/terpukul-corona-ini-5-keluhanpara-pelaku-umkm (2020)

8. Kapil Dahiya, Ali Potia, Resil Das, Denny Praseco, Survey: Indonesian consumer sentiment during the coronavirus crisis, McKinsey \& Company Survey, retrieved from https://www.mckinsey.com/business-functions/marketing-and-sales/ourinsights/survey-indonesian-consumer-sentiment-during-the-coronavirus-crisis (2020)

9. Gugus Tugas Percepatan Penanganan COVID-19 Indonesia, Lima Skema Perlindungan dan Pemulihan UMKM di Tengah Pandemi Covid-19, retrieved from https://covid19.go.id/p/berita/lima-skema-perlindungan-dan-pemulihan-umkm-ditengah-pandemi-covid-19 (2020)

10. Bank Rakyat Indonesia. Annual Report Bank Rakyat Indonesia 2019 (2019).

11. Kementerian Perencanaan Pembangunan Nasional Republik Indonesia/Badan Perencanaan Pembangunan Nasional, Draft of National Medium Term Development Plan (RPJMN) 2020-2024, Jakarta (2020)

12. Tulus Tambunan, Recent evidence of the development of micro, small and medium enterprises in Indonesia, Journal of Global Entrepreneurship Research, 9(1), 18. (2019)

13. Gary Dessler, Human Resource Management (13th ed.), New Jersey: Pearson Education, Inc (2013)

14. I Nyoman Sumaryadi, Perencanaan Pembangunan Daerah Otonom dan Pemberdayaan Masyarakat, Jakarta: Citra Utama (2005) 
15. Robert D. Hisrich, Michael P. Peters, Dean A. Shepherd, Entrepreneurship (9th ed.), New York: McGraw-Hill Education (2013)

16. Sugiyono, Metode Penelitian Kualitatif (3rd ed.), Bandung: Alfabeta (2017)

17. Burhan Bungin, Penelitian Kualitatif: Komunikasi, Ekonomi, Kebijakan Publik, dan Ilmu Sosial Lainnya (2nd ed.), Jakarta: Kencana (2017).

18. Gary Thomas, A Typology for the Case Study in Social Science Following a Review of Definition, Discourse, and Structure, Qualitative Inquiry, 17(6), 511-521 (2011)

19. Arthur A. Thompson, John E. Gamble, Margaret A. Peteraf, A.J. Strickland III, Crafting \& Executing Strategy: The Quest for Competitive Advantage Concepts and Cases (21th ed.), New York: McGraw-Hill Education (2018)

20. BRI Microfinance Center, Annual Report BMC (2019)

21. Pemerintah Republik Indonesia, Law of the Republic of Indonesia Number 20 of 2008 on Micro, Small, and Medium Enterprises, Lembar Negara Republik Indonesia, Tahun 2008 Nomor 93, Sekretariat Negara, Jakarta (2008)

22. Pemerintah Republik Indonesia, Peraturan Presiden Nomor 2 Tahun 2015 tentang Rencana Pembangunan Jangka Menengah Nasional (RPJMN) Tahun 2015 - 2019, Lembar Negara Republik Indonesia Tahun 2015 Nomor 3, Sekretariat Negara, Jakarta (2015)

23. Bank Indonesia, Five Finger Philosophy: Upaya Memberdayakan Usaha Mikro, Kecil, dan Menengah, eetrieved from https://www.bi.go.id/id/umkm/koordinasi/filosofi-limajari/Contents/Default.aspx.

24. Sakina Rakhma Diah Setiawan, Sebanyak 37.000 UMKM Terdampak Virus Corona, retrieved from https://money.kompas.com/read/2020/04/17/051200426/sebanyak37.000-umkm-terdampak-virus-corona (2020)

25. Dewi Rina Cahyani, 47 Persen UMKM Bangkrut Akibat Pandemi Corona, retrieved from https://bisnis.tempo.co/read/1344540/47-persen-umkm-bangkrut-akibat-pandemicorona/full\&view $=$ ok $(2020)$

26. Rais Agil Bahtiar, Juli Panglima Saragih, Dampak Covid-19 Terhadap Perlambatan Ekonomi Sektor UMKM, Info Singkat, Kajian Singkat Terhadap Isu Aktual dan Strategis, Jurnal Pusat Penelitian Badan Keahlian DPR RI, XII(6), 19-24 (2020)

27. Gugus Tugas Percepatan Penanganan COVID-19 Indonesia, Sistem E-Commerce Jadi Solusi Bagi Pelaku UMKM di Tengah Pandemi COVID-19, retrieved from https://covid19.go.id/p/berita/sistem-e-commerce-jadi-solusi-bagi-pelaku-umkm-ditengah-pandemi-covid-19 (2020)

28. Aamer Baig, Bryce Hall, Paul Jenkins, Eric Lamarre, Brian McCarthy, The COVID-19 recovery will be digital: A plan for the first 90 days, retrieved from https://www.mckinsey.com/business-functions/mckinsey-digital/our-insights/theCOVID-19-recovery-will-be-digital-a-plan-for-the-first-90-days?cid=other-eml-alt-mipmck\&hlkid=e885cfa20aa8478a971 cb2222fd812ec\&hctky $=10047063 \&$ hdpid $=$ cdd689aa -d6fd-4146-9805-d8e36926b233 (2020)

29. Kementerian Perindustrian, Making Indonesia 4.0, Handbook (2018)

30. Wikipedia, COVID-19 pandemic in Indonesia, retrieved from https://en.wikipedia.org/wiki/COVID-19_pandemic_in_Indonesia (2020) 